3. Michael A. Mobile Marketing. Creating a competitive advantage with the help of wireless technologies: per. from english /AND. Michael, B. Solter; [per. from english O. B. Dutova]. - Moscow: «IDT Group Ltd.», 2007. $-400 \mathrm{p}$.

4. Mobile Blind: How do smartphones make people less impulsive? [Internet resource]. - Access mode: https://lpgenerator.ru/blog/2015/02/ 25/ mobilnaya-slepota-kak-smartfony-delayut-lyudej-menee-impulsivnymi

5. Farkosh O. Catch the moment. Digitalization of business / O. Farkosh [Internet resource]. - Access mode: https://eba.com.ua/article/lovymoment-didzhytalizatsiya-biznesu/

6. How the main media will evolve - television, Internet, outdoor advertising and the press [Internet resource]. - Access mode: https://adindex.ru/specprojects/ marketing-trends-2018/168338.phtml

7. The digitalization of advertising is inevitable [Electronic resource]. Access mode: https://posterscope.com.ua/en/posts/didzhitalizatsiyareklamy-neizbezhna

DOI: http://doi.org/10.31617/k.knute.2019-03-19.02

\title{
PECULIARITIES OF CURRENCY DEPENDENCY - ASPECT OF TRADING AND PRODUCTION
}

\author{
Burkle N. \\ $\mathrm{PhD}$, Associate Professor \\ Schiller International University, Germany
}

Keywords: monetary policy, international trading.

Due to the transition to the policy of floating exchange rate, currently undertaken by many countries of the world, the impact of exchange rates on domestic production becomes particularly important. Growth strategy of manufacturing companies, conducting cross-border financial operations, requires mandatory consideration of the impact of the exchange rate on output. The issue of effective accounting of the exchange rate fluctuations in the strategies of the companies has become particularly acute over the last years. As a result, import substitution has become one of the leading strategic lines of development for the companies. This paper is aimed to present the impact of currency dependency on trading and manufacturing on the examples of Switzerland. The article analyzes theoretical approaches to the assessment of the real exchange rate impact on the manufacturing companies' output. 
Strategic management in modern companies comes to the foreground among other types of management activities. It is caused by the increasing uncertainty of the business environment, growing competition and its globalization, development of information and communication technologies and other factors described in the literature (Mintzberg, Quinn1996; Nag, Hambrick, Chen 2007; Porter 1980). The key aspect of strategic management is to overcome the uncertainty of the future

The issues of the exchange rate dynamics are considered not only as part of the strategic analysis, but also as that of the theory of international monetary policy. One of its main ideas is to determine the mechanism of the relationship between the exchange rate, domestic production and inflation. These results can be directly used when developing strategies of companies whose activities are related to cross-border operations.

On the example of Swiss Frank we are presenting the impact of currency dependency on trading and manufacturing.

The Swiss Frank was long somehow fixed to the Euro, with the ratio of $1.00 \mathrm{CHF}=1.20$ Euro. This was all true, until the 1st January $2014-$ when this dependency was lifted and the Swiss Frank gained value and dropped within a week to $1.00 \mathrm{CHF}=1.00$ Euro.

At the first blink - this seems to be very little change - only $20 \%$. However, manufacturing in Switzerland suffered. What happened - as an example to the Swiss Train manufacturer STADLER at Bussnang.

STADTLER Bussang:

Is an international train manufacturer, who started pretty much from near zero in 1990- with only 20 employee when Peter Spuhler too the company over- and became within nearly 30 years to one of the big global players with nearly 8.000 employees and 2.5Billion Euro turnover. STADLER had mainly manufacturing sites in Switzerland - taking over former Production sites of SLM (Schweitzer Lokomotiv Manufactur), Sulzer, Swiss Metal Casting AG - and other sites, like former airplane assembly sites of Dornier. The big global players are Bombardier, Siemens, Alstom, Hitachi, GE, Hyundai and many more.

STADLER was successful by being very innovative and customer oriented, and they designed 4 new platforms for trains - like the GTW, Flirt, Kiss and the Geronimo for the regular train systems (Traction rail systems). Aside of them, they have the gear train manufacturing, climbing up steep hills with gear interaction to the rail track. This devision has a monopoly position world wide - since no other company focuses on this small train divisions, with nearly infinite amount of rail track sizes - making every client and order unique. 
STADLER focuses heavily on the client use and interaction, as well as very stylish train designs - making them to the most attractive trains from the outside and inside.

The problem of STADLER is the heavy manufacturing content in the Swiss factories. These value added amount is made with high Swiss hour rates - being higher then in the European Region. On top, the Swiss Frank gained over night nearly $20 \%$.

The sole solution was, to import more components from Germany - to counter act the high Swiss Frank, and in long term, maybe produce as much of the trains in the European Region - to counteract the fast change of exchange rate. If the efficiency of working would be $20 \%$ more efficient over night in Switzerland, compared to the European Union, then this increase in currency value could be accepted.

What did the STADLER company do in the short term. They demanded from their employees more work hours - to lower the hourly expenses - increasing from 38 hours per week to 42 hours per week for the same pay. In long term, their purchasing department focuses to purchase more components and subcomponents from the European Union - to lower the dependency of currency exchange.

An example: If a train costs $1.0 \mathrm{Mio} \mathrm{CHF}$ - with $20 \%$ components of the European Union - then the remaining 800.000CHF are effectively $20 \%$ more expensive - or $160.000 \mathrm{CHF}$ more expensive theoretically - if the train is sold into the European Union with the EURO as currency. The currency jump is therefore $16 \%$ of the final product price.

An example: If a train costs $1.0 \mathrm{Mio} \mathrm{CHF}$ - with $20 \%$ components of the European Union - then the remaining 800.000CHF are effectively $20 \%$ more expensive - or $160.000 \mathrm{CHF}$ more expensive theoretically - if the train is sold into the European Union with the EURO as currency. The currency jump is therefore $16 \%$ of the final product price.

If a train costs $1.0 \mathrm{Mio} \mathrm{CHF}$ - with $80 \%$ components of the European Union - then the remaining $200.000 \mathrm{CHF}$ are effectively $20 \%$ more expensive - or $40.000 \mathrm{CHF}$ more expensive theoretically - if the train is sold into the European Union with the EURO as currency. The currency jump is therefore $4 \%$ of the final product price.

The interrelationship between national production and national currency rate was studied by many economists in both developed and developing countries. They obtained different results, which was caused by the specifics of a particular economic situation, as well as by an economic model that was used. There is no universal opinion on the impact of the exchange rate on domestic production. This creates uncertainty in the development of strategies for manufacturing companies engaged in cross- 
border transactions. We have made a conclusion that it is necessary to conduct a special study of the mutual influence of the exchange rate and production on the materials of the particular economy of the country. Theoretical developments carried out on the materials of other countries do not always give adequate results in terms of other specific country. So it is not recommended to use them without special checking for the strategic management of the companies.

An international manufacturer should always do his homework depending on which market he sells. If the manufacturing process is very labor intense - then the majority of the assembly or manufacturing process should be in the cheaper country - or in the country where the products are sold finally - to avoid currency fluctuations. This is very important in large markets - like Europe vs. North America (USA and Canada) - or in Markets like South America - with high inflation rates - where every import would face monthly need price adjustments - due to double digit inflation rates in the past.

A similar issue is with the Chinese Yuan. The Yuan is fixed with 8 Yuan to the US Dollar. This might cause one day a big issue - on a much larger scale - compared to the Swiss Frank and Euro issue of 2014.

The company STADLER does not longer expand in Switzerland. It has opened since 2012 mainly assembly and manufacturing plants all over Europe - mainly in the Eastern European Regions - where hourly rates are lower - and are future markets - to reduce the currency exchange problems. There are also many plants now in Germany - but mainly due to hostile takeover or to secure maintenance contracts of the products of these regions.

Another tool in international trading is, by using a Currency Exchange Rate Insurance - which costs in the region of 1\% of the trading value - and fixes the currency exchange rate to the value of the contract it was negotiated. This is important - if a contract is signed, but the delivery and payment steps are further down the road in the range of being years away. Machines, equipment and investment goods normally have to be produced, once the contracts have been signed

\section{References}

1. Babkin, A.V., Kudryavtseva, T.Ju. (2015). Identification and Analysis of Instrument Industry Cluster on the Territory of the Russian Federation. Modern Applied Science, 9 (1), 109-118.

2. Burstein, A., Neves, J.C., Sergio, R.S. (2014). Investment Prices and Exchange Rates: Some Basic Facts, NBER Working Paper.

3. Carneiro, F.G. (2003). Devaluation, output and wages. International economic journal, 17, 15-27. Chia-Hsun Hsieh \&Shian-Chang Huang 
(2016) Department of Business Administration, National Changhua University of Education, Taiwan Emerging Markets Finance and Trade Volume $48,-$ is. 2.

4. Edwards, S. (1987). Are Devaluations Contractionary? NBER Working Paper.

5. Holdberg, L.S. (2002). Exchange Rate Pass-Through into Import Prices: A Macro or Micro Phenomenon? NBER Working Paper.

6. Ignatieva Katja (2017) Using Dynamic Copulae for Modeling Dependency in Currency Denominations of a Diversified World Stock Index,Eckhard Platen \&Renata Rendek Journal of Statistical theory and practice, volume 2 .

7. Kartaev, F.S. (2009). Modeling the impact of currency exchange rate on GDP dynamics: Thesis Abstract. Moscow.

8. Forbes, K.J. (2002). Cheap Labor Meets Costly Capital: The Impact of Devaluations on Commodity Firms. NBER Working Paper, No 9053.

9. Froot, K.A., Stein, J.C. (1992). Exchange Rates and Foreign Direct Investment: An Imperfect Capital Markets Approach, NBER Working Paper.

10. Kadochnikov, P., Sinelnikov-Murylev, S., Chetverikov, S. (2003). Import Substitution in the Russian Federation in 1998-2002, Moscow.

11. Kamin, S.B., Klau M. (1998). Some multi-country evidence on the effects of real exchange rates on output. Board of Governors of the Federal Reserve System, International Finance Discussion Papers,

12. Klein, M.W., Rosengren, E. (1992). The Real Exchange Rate and Foreign Direct Investment in the United States: Relative Wealth vs. Relative Wage Effects, NBER Working Paper, 4192.

13. Elena Malykh et al. / Procedia - Social and Behavioral Sciences 207 (2015).

14. Quinn, J.B. (1996). The Strategy Process: Concepts, Contexts, Cases. Prentice Hall.

15. Nag, R., Hambrick, D. C., Chen, M.-J (2007). What is strategic management, really? Inductive derivation of a consensus definition of the field. Strategic Management Journal, 28 (9), 935-955.

16. Plotnikov, V., Vertakova, J. (2014). Manufacturing industry in Russia: problems, status, prospects. Procedia Economics and Finance, 14, 499-506.

17. Porter, M.E. (1980). Competitive Strategy, Free Press.

18. Rodionov, D.G., Nikolova, L.V., Mokeeva, T.V. (2014). The formation of the conflicts management models of the strategic alliances under the conditions of the globalization. Asian Social Science, 10 (19).

19. Tovar, C.E. (2008). Devaluations, output and the balance sheet effect. Bank for International Settlements, Central Bank of Indonesia. 